\title{
A Humanist God? On the troubled Relationship Between Humanism and Religion Today
}

\author{
Marco Russo \\ University of Salerno, Fisciano, Italy
}

\begin{abstract}
The relationship between humanism and religion has always been difficult, since the Renaissance. If we look at the Humanist Associations active today in the world, we find that the relationship has become almost a declared war. Religion appears to be the greatest enemy of humanism, i.e., of the humanity. Authentic humanism seems to be exclusively secular and atheistic: you can do good only if there is no God. In this contribution I look at some programmatic documents of Humanist Associations to understand the reasons for this contrast, in the background of secularization. The result is that some criticisms of religion — its potential for violence and obscurantism — are historically and theoretically justifiable but partial. Indeed, they show a poor and narrow vision of religion that leads to a narrow view of the human experience. A more complex vision of man requires a more complex vision of religion. A complex vision of man includes the most "irrational” and enigmatic aspects of our being, as love, death, pain, desire, imagination and even freedom and creativity. On this basis we can appropriately understand the historical and existential role of religion. Otherwise, if God is the one painted by humanists, God would not be good, let alone a good humanist.
\end{abstract}

Keywords: humanism, religion, Humanist Associations, secularism, secularization complexity, existence, transcendence

\section{Introduction}

The humanism-religion relationship is very strictly on historical and theoretical level. Historically, it is the core of the process of secularization. Theoretically, there are crucial questions about the nature of Christ, the phenomenology of religion, the nature of morality, the sense of anthropocentrism.

A perspective that, in the contempoarary age, allows the two levels to overlap is provided by humanistic associations. Preceded by various types of "Ethical Unions" born in the 19th century, they were founded in the 20th century in the United States and England, but also, in parallel, in South America, and then have had a remarkable diffusion in many parts of the world.

Humanists have been very active in charitable work, education and social reform, and campaigning for human rights, peace and international co-operation. At the United Nations, UNESCO (United Nations Educational, Scientific and Cultural Organisation), FAO (Food and Agriculture Organization), WHO (World Health Organization), were all led by humanists in their early years.

Their philosophical position is condensed in the motto: Good without God. But they are not just theorizing humanism, they intend to practice it, make it a lifestyle (Copson \& Grayling, 2015; Norman, 2006). This is a

Marco Russo, Assistant Professor, Department of Cultural Heritage (DISPAC), University of Salerno. 
particularly important aspect. While in the 20th century the sophisticated philosophical controversy raged on the theme of "humanism" (Heidegger, Sartre, Maritain, Lubac, Foucault...) (Toussaint, 2008; Rockmore, 1994). these associations tried to practice it in everyday life, from below, with a pragmatic spirit. They and we with them ask ourselves: Is it possible to do good, to live according to justice, with a cooperative spirit, without any faith and/or trascendence? Would God be a good humanist?

\section{Renewing Religion: Reading Some Humanist Associations Texts}

In 1933 appeared Humanist Manifesto I, signed by 33 intellectuals (including John Dewey). It is the presupposition of the AHA foundation in 1941. The first Manifesto talked about a "new religion" and referred to humanism as a religious movement to transcend and replace previous religions based on allegations of supernatural revelation. Charles F. Potter, one of the co-authors of the Manifesto, had already written a book eloquently entitled Humanism: A New Religion (1930).

The genesis of the Manifesto was told by Edwin Wilson, who was one of its authors together with Charles Potter and Raymond Bragg. All three were Unitarian ministers. Wilson writes: "The way for humanism in Unitarianism had been opened when the measures and foundations of truth and morality were placed outside of the Holy Bible and within human reason and moral conscience. Thus, as Unitarianism grew, religious humanism began to appear long before proponents had a name for it. By its rejection of revelation, religious humanism was inherently opposed to biblical literalism, dogmatism, and religious creeds” (Wilson, 1995, p. 9). Wilson also recalls the careful search for one "verbal integrity and a semantic change from traditional religious terms in order to clarify their naturalistic approach"; he observes that "the manifesto framers were careful to disclaim the document as a creed, which it has nonetheless been interpreted as such” (Wilson, 1995, p. 40).

Despite its religious roots American humanism has a decided secular outlook. In Humanist Manifesto Iwe read: "Religions have always been means for realizing the highest values of life [...] Religion itself remains constant in its quest for abiding values, an inseparable feature of human life” (Preamble).

Humanism recognizes that man's religious culture and civilization, as clearly depicted by anthropology and history, are the product of a gradual development due to his interaction with his natural environment and with his social heritage (Humanist Manifesto I, paragraph 4). Religion must formulate its hopes and plans in the light of the scientific spirit and method (ibid., paragraph 5). Religious Humanism considers the complete realization of human personality to be the end of man's life and seeks its development and fulfillment in the here and now (ibid., paragraph 8). In the place of the old attitudes involved in worship and prayer the humanist finds his religious emotions expressed in a heightened sense of personal life and in a cooperative effort to promote social well-being (ibid., paragraph 9). We assume that humanism will take the path of social and mental hygiene and discourage sentimental and unreal hopes and wishful thinking (ibid., paragraph 11).

\section{Humanist Manifesto II (1973)}

Those who sign Humanist Manifesto II disclaim that they are setting forth a binding credo. They concede that religion may inspire dedication to the highest ethical ideals. The cultivation of moral devotion and creative imagination is an expression of genuine "spiritual" experience and aspiration. Neverthless "traditional dogmatic or authoritarian religions that place revelation, God, ritual, or creed above human needs and experience do $a$ disservice to the human species [...]”. Traditional religious morality deny humans a full appreciation of their own potentialities and responsibilities. The final warning is peremptory "No deity will save us; we must save ourselves". 


\section{Humanist Manifesto III (2003)}

Here, the bond with religion is cut off. You no longer need to discuss it and take a stand against it. It's directly stated: "Humanists find that science is the best method for determining this knowledge as well as for solving problems and developing beneficial technologies. Humans are an integral part of nature, the result of unguided evolutionary change. Ethical values are derived from human need and interest as tested by experience. Humanism is a progressive philosophy of life that, without supernaturalism, affirms our ability and responsibility to lead ethical lives of personal fulfillment that aspire to the greater good of humanity. Humanity has the ability to progress toward its highest ideals”.

\section{The Amsterdam Declaration (2002)}

This declaration is a statement of the fundamental principles of modern humanism passed unanimously by the General Assembly of the International Humanist and Ethical Union (IHEU). The specific point on religion states "Humanism is a response to the widespread demand for an alternative to dogmatic religion [...] Humanism recognizes that reliable knowledge of the world and ourselves arises through a continuing process of observation, evaluation and revision”.

\section{Short Course of Humanism (2007)}

In this introductive text the BHA clearly lists the reasons for not having faith: (1) Religions claim things to be true for which there is no supporting evidence, and encourage belief in the unbelievable and superstition. (2) The rigidity of religious codes of behavior stifle our opportunity to think and act rationally, and sometimes, ethically. (3) Ancient religious rules are unhelpful when thinking about new moral issues, where reason and compassion are more useful. (4) Religious authority has been, and still some time is, used to justify oppression, discrimination, an injustice (for example, against women, gay people particular races, and other religious groups). (5) Religious differences have been, and still sometime are, a major cause of war, even when religious leaders preach peace. (6) Religious authority is often used to justify puritanical and pointless repression of pleasure. (7) Religious authorities often stifle free debate. (8) The idea that there is a "better life" in a "better place" devalues this life and this world (p. 13).

For these reasons it's false that religion is the source of morality. Morality is indipendent from and much more necessary than religion. The main motivation to behave well and live a good life is found in human nature and society. To survive and live well, we need to live harmoniously and co-operatively in communities. Moral is a product of the biological and social evolution. After all is our common human nature that explains the considerable agreement between religions, societies, and ethical and legal systems, about what is good or bad. Humanists have been impressed with the apparently universal nature of the Golden Rule, "Do as you would be done by" or "Treat other people in a way you would like to be treated yourself". All traditions seem to have come up with a version of it. It can be formulated both positively (as above) and negatively ("Don't do things to other people that you wouldn't like done to you").

We should base our moral choices on the reasonably predictable effects of actions. Empathy and feelings are further sources and tools of moral.

\section{Comment and Criticism}

The reading of these texts leads to the following observations:

(1) contemporary humanism completes secularization, understood as the "age of reason", that is, as the 
downfall of faith, of the public relevance of religion;

(2) contemporary humanism outlines itself by a systematic contrast to religion, considered as an impediment to moral and rational knowledge which are in turn considered as the only means to improve the human condition;

(3) contemporary humanism replaces the social and cultural function of religion by eliminating its negative aspects (irrationalism, obscurism, repression, violence) and reinforcing positive ones (intersubjective bond, rituality, morality, search for meaning, expectation of happiness).

The first point confirms that humanism is a tenet of modernity (Russo, 2015; Buck, 1987). Between the Renaissance and Enlightenment there is a "humanist family" (Todorov, 2002) that goes from Petrarca to Montaigne, from Machiavelli to Hume, from Pascal to Kant. The focus of this family is the human condition taken in itself, in its internal complexity; a complexity that no religious or purely metaphysical conception is enough to explain and solve. Physical, psychic, historical, geographical and socio-political aspects become more and more important to explain the human being and to build a well-balanced society. Man (and not only nature or God) is capable deciding his destiny.

There are basic contrasts between a theistic and a humanistic standpoint, because where religion prevails, man is not the centre and not the end of knowledge. Although, modern humanism does not intend to replace God by man, making him the master of the world. Humanity is an ideal, a task, a collective achievement, not a fixed feature to bring to light. It is necessary to develop a human culture, that is to cultivate values, lifestyles inspired by an idea of common good extended to the greatest number of people, rejecting merely instrumental reason, market logic, power relationships, cynicism of the private or national interests. The ultimate end of our actions is cultivating humanity, not superhuman entity (God, goodness, justice) but much less merely infrahuman ones (pleasures, money, power).

The great discovery of modern humanism is that there are purely immanent values - not just goods - like detached benevolence, solidarity, awe for the moral law, universal sympathy, which can be promoted by building a universal civilization, that is under certain conditions of training, discipline affirming non-punitive upbringing (Taylor, 2007). The core issue is that the roots of these values and of universal order are religious or metaphysical (if metaphysicsis rational investigation of what goes beyond nature). Now, letus leave aside the "political theology", the translation of religious concepts into secular concepts. I prefer rather to emphasize that it's within the study of man, within Immanence, that modern humanism, more philosophically aware, has found the signs of Transcendence. To explain the human condition, its structural contradictions, its "strangeness" in nature, it seems to be necessary to suppose a beyond: to go beyond the given, the present, the material possessions. Such a beyond is a religious element, but we use it also in metaphysics, anthropology, psychology... almost to explain the fact of religious experience!

This leads to reflection on the second point. It is true that there is a close connection between secularism and humanism. Lay state, scientific rationality, human rights, the anthropological re-interpretation of metaphysics and theology are certainly the Enlightenment's response to the bloody wars of religion triggered by the Reformation. However, a secular state does not necessarily mean a secular society. Science is never completely neutral, nor is it able to absorb all reality in itself. Human rights rely on anthropology that elaborates metaphysical concepts (freedom, dignity, fraternity, moral conscience). In short, secularization is not a simple downfall of religion but a transformation of the conditons of belief (Taylor, 2007). The loss of the centrality of the theistic source has also been the discovery of new sources of moral experience, more directly 
related to the concrete experience of men. The constitutive tentativeness and the pluralization of moral sources have been an epistemic gain in understanding the good and how to enhance earthly life (Taylor, 1989). Christianity itself has been induced to recognize the value of the saeculum, the secular meaning of Jesus' incarnation.

Humanism, therefore, does not coincide with radical Enlightenment, that is, with an "intellectual atheism" (BHA, 7) that liquidates religion as the infant stage of human development. The history of the concept of humanism is intertwined with the criticism of religion, but not in the sense of its pure elimination but of its rethinking. The "drama of atheist humanism" (Lubac, 1987) is that it holds a dramatic connection with what it denies. On the one hand, hatred against religion shows that it is attributed enormous power and appeal. On the other hand, atheist humanism proposes itself as a religion for its ecumenical will to regenerate the world. More and better than the great intellectual figures of atheist humanism (from Libertins to Feuerbach, Marx, Comte, Sartre, Russell), humanist associations clearly show this need to produce ties, establish values, and ritualize behaviors. Humanists form communities, celebrate weddings, funerals, parties. They publish books and programs to spread their ideas, their own creed.

So I'll get to the last point. Humanism considers religion not only useless but dangerous because it obstructs reason, it's repressive and often causes war. In my opinion this is a partial and somewhat inconsistent reading. Inconsistent because humanism wants to replace religion, that is, to play its social and symbolic role in a rational and controllable way. There are of courselay rituals (from concerts to sports), there are of course purely secular values and rules. But alone they do not seem to be able to involve individuals deeply or steadily. Religion plays its communitarian role and affects individuals because it goes beyond ordinary reason and compensates for its limits: it is a faith. To be a faith must have elements of mystery, transcendence, sacredness, consolidated through a longlasting tradition. As long as there are "irrational" aspects in life (or rather aspects that have a different, non-standard logic) it's difficult that rationality will be able to fully absorb them. Just remember the "border-situations" (Jaspers, 1994) of pain, death, guilt, shipwreck, but also ecstasy, plentifullness, dizziness that destabilize our existence. As much as our knowledge has grown tremendously, we continue to have make a lot of effort to grasp social phenomena such as violence, excess, neurosis, craving, squandering, the need to express ourselves, to create, etc. And indeed, religion has resisted secularization, capitalism, and globalization.

Furthermore, humanists make a partial reading of religion. Certainly religion can have violent aspects. But it is always very difficult to determine how much this violence depends on the use (political, social, economic) of religion or if it belongs to its true message. It's also difficult to see what is happening in our societies if there would be no more faith and no religious institution at all. It is difficult to imagine it because our societies have until now never been totally secular; the identity and channeling factor of religions still continue to act. Even in the most advanced secular society religion is present as a permanent object of criticism or as the alter ego of pure immanence. It does not seem to be eliminated as interlocutor or even as a challenge. That is why we now also speak of a "post-secular" society (Habermas, 2012) as the attempt to balance mutual self-restraint between faith and knowledge, secularism and religion. It seems unlikely that the millennial contribution of religion in human history as a source of myths, rites, symbols, prohibitions, hopes can be reduced to superstition and violence. Religion has contribuited to set up and contain the - dramatic, troubled, unbalanced - humanity of human being. 
In conclusion, humanist associations allow the strength and weakness of atheistic secularism to be assessed. They show the power of the idea of humanity: to build a just and balanced society made by men for men, sharing a common destiny. They show that humanism can be a "good practice", even before being a theory or a ideology: how to learn to live as someone else's neighbor. But they also highlight that there is nothing more anti-humanistic than relying on a simplified, one-dimensional, shallow model of man and reason. Contemporary humanist's writings are often based on such a model. In this way they betray the original spirit of humanistic tradition. They confuse it with post-Enlightenment atheism, with Positivism. In short: Without God there can be good humanism, but just because God is far from its humanistic image. God will never be a good humanist.

\section{References}

AHA (American Humanist Association). (n.d.). Humanist Manifesto I-II-III. Retrieved from https://americanhumanist.org/what-is-humanism/manifesto3/

BHA (The British Humanist Association). (n.d.). A short course on humanism. Retrieved from https://humanism.org.uk/humanism/

Buck, A. (1987). Humanismus: Seine europäischeEntwicklung in Dokumenten und Darstellungen (Humanism: Its European development through documents and pictures). Freiburg: Alber.

Copson, A., \& Grayling, A. C. (2015). The Wiley Blackwell Handbook of Humanism. London: Wiley Blackwell.

Habermas, J. (2012). NachmetaphysischesDenken II. Aufsätze und Repliken (Post-metaphysical Thinking 2). Frankfurt a. M.: Suhrkamp.

IHEU (International Humanist and Ethical Union). (n.d.). What is Humanism. Retrieved from http://iheu.org/humanism/what-is-humanism/

Jaspers, K. (1994). Psychologie der Weltanschaaungen (Psychology of Worldview). München: Piper.

Lubac, H. D. (1987). Le Drame de l'humanismeathée (The Drama of atheist Humanism). Paris: Les Editions du Cerf.

Norman, R. (2006). On humanism. London and New York: Routledge.

Rockmore, T. (1994). Heidegger and French Philosophy: Humanism, antihumanism and being. London and New York: Routledge.

Russo, M. (2015). Umanesimo: Storia, critica, attualità (Humanism: History, Critics, Topical Issues). Firenze: Le Lettere.

Taylor, C. (1989). Source of self: The making of modern identity, 1989. Cambridge Massachussets: Harvard University Press.

Taylor, C. (2007). A secular age. Cambridge Massachusetts and London: Belknap Press.

Todorov, T. (2002). Imperfect garden: The legacy of humanism. Princeton and Oxford: Princeton University Press.

Toussaint, S. (2008). Humanismes, Antihumanismes De Ficin à Heidegger (Humanism, Anti-Humanism: From Ficin to Heidegger). Paris: Les Belles Lettres

Wilson, E. (1995). The genesis of a humanist manifesto. New York: Humanist Press. 